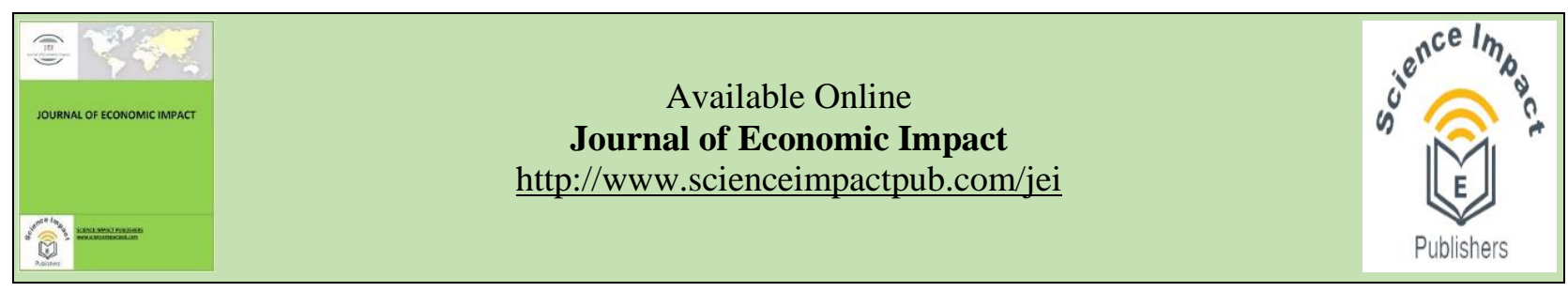

\title{
PROFITABILITY ANALYSIS OF GINGER VALUE ADDITION IN ABIA STATE, NIGERIA
}

\author{
Ndubuisi Chigozirim Onwusiribe ${ }^{\mathrm{a}, *}$, Chimarauche Peace Amanze ${ }^{\mathrm{b}}$, Chinwendu Oriaku ${ }^{\mathrm{a}}$

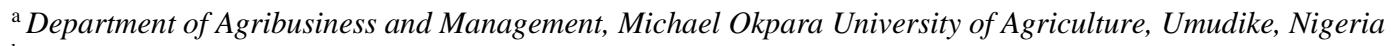 \\ ${ }^{\mathrm{b}}$ Alvan Ikoku Federal College of Education Owerri, Nigeria
}

\section{HIGHLIGHTS}

- Ginger farm enterprise was found to be very profitable as there are many value-added products that can be derived from the production.

- Farmers should note that the training, capital, and collateral are main factors affecting the profitability of ginger value addition.

- Training of entrepreneurs will equip them to enhance their value addition skills while the availability of capital and collateral will provide the finance for acquiring the necessary value addition technology.

- Better extension services are urgently required for improved technologies and the provision of lowcost capital will assist farmers in the process of value addition.

ABSTRACT
This study analyzed the profitability of ginger value addition in Abia State, Nigeria. This study identified
the ginger value-added products common in the area, the cost implications of the value addition process, and
the socio-economic and farm-specific factors affecting ginger value addition. A stratified random sampling
technique was used to select 60 (sixty) respondents and a well-structured questionnaire was used to collect
the necessary data. The results revealed that the value ginger products were dried ginger, salted ginger, ginger
flakes, ginger oil, and ginger paste. The factors affecting the profitability of ginger value addition from the
linear regression model shows that education, income, capital, and collateral were significant. It is, therefore,
recommended that youth and entrepreneurs should invest in ginger value addition as it is profitable and it is
a sure way to economic empowerment and fight against hunger.

Keywords: Profitability, value addition, factors, linear regression model, Nigeria.

Received: Sep 29, 2019; Accepted: June 03, 2019; Published: June 26, 2020.

* Correspondence: Department of Agribusiness and Management, Michael Okpara University of Agriculture, Umudike, Nigeria.

Email: ndubuisichigo@gmail.com

\section{Introduction}

Ginger (Zingiber officinale) is a perennial crop of order Scitamineae and the family Zingiberaceae. Ginger is a root crop with the characteristics of a typical herb grown across the world for its underground stem or rhizome which has nutritional and medicinal value (FAO, 2010). Ginger is an economic crop demanded all over the world, this makes it an important commercial with a great export value in world trade (Erinle, 1988; Ajibade \& Dauda, 2005). Ginger is well adapted to the varying climatic condition in different parts of Nigeria, the major states where this economically and nutritionally important crop is cultivated are
Kaduna, Nassarawa, Sokoto, Zamfara, Akwa Ibom, Oyo, Abia and Lagos states (FAO, 2005). The varieties produced in Nigeria are 'Taffin Giwa' and 'Yatsun Biri' which is comparatively higher in monoterpene and oil, giving a more pungent aroma.

It is recognizable that the actual yield of ginger in Nigeria is below the expected yields in terms area cultivated and harvested especially when compared to the yield of other nations that produce ginger in large quantities. One major challenge to ginger production in Nigeria is the very narrow gene pool on which the industry is based and the low level of 
acceptance of improved varieties by the farmers. Most ginger farmers have bad cultural practices such as the failure in managing many weeds and harvesting at the proper time and by using the correct methods (Orkwor \& Melifonwu, 1988).

Another major challenge to the ginger production and value addition is the use of manual and crude techniques of production and process, there is a very low level of automation and mechanization among ginger farming and value addition enterprises (Ewuziem \& Onyenobi, 2012). Secondly, the cost of production is relatively high, because of the increased cost of labor and high prices of other inputs. Ginger is perishable and giving the poor state of storage and other infrastructural facilities in Nigeria, post-harvest losses are massive, thus, there is market glut during harvest periods and marked scarcity during offseasons. This phenomenon makes the need for value addition (such as processing and packaging) very pertinent to improve the shelve life of the crops and to attract a fair price to the farmers. This study examined the profitability of ginger value addition enterprises in Abia State, Nigeria.

\section{Methodology}

This work was carried out in Abia State, Nigeria. It has seventeen local government areas that are divided into three agricultural zones namely Ohafia, Umuahia, and Aba (Nto et al., 2011). The study was carried out in three geo-political zones (Abia North, Abia Central, and Abia South) of Abia state. The researcher used a random sampling technique.

For the purpose of data collection a wellstructured questionnaire was prepared. Data were collected from 60 respondents chosen through stratified sampling techniques. Descriptive statistics were used to analyse objective one and two respectively, objective three was analysed using cost and return analysis while objective four was analysed using multiple regression analysis. The hypothesis was tested using the F-test statistics.

\section{Model specification}

Following multiple regression model was employed that is implicitly stated as;

$$
Y=f\left(X_{1}, X_{2}, X_{3}, X_{4}, X_{5}, X_{6}, X_{7}, X_{8}, X_{9}, X_{10}\right)
$$

The explicit form of the model is stated as

$$
\begin{gathered}
Y=\beta_{0}+\beta_{1} X_{1}+\beta_{2} X_{2}+\beta_{3} X_{3}+\beta_{4} X_{4}+\beta_{5} X_{5}+\beta_{6} X_{6}+ \\
\beta_{7} X_{7}+\beta_{8} X_{8}+\beta_{9} X_{9}+\beta_{10} X_{10}+\mu
\end{gathered}
$$

\section{Where;}

$\mathrm{Y}=$ Quantity of value added ginger (numbers)

$\mathrm{X}_{1}=$ Level of education and training of the entrepreneur measured in years

$\mathrm{X}_{2}=\operatorname{Gender}($ male $=1$ and female $=0)$

$\mathrm{X}_{3}=$ Experience of the entrepreneur measured in years

$\mathrm{X}_{4}=$ Household size of the entrepreneur measured in numbers

$\mathrm{X}_{5}=$ Farm size in $\mathrm{km}$

$\mathrm{X}_{6}=$ Type of capital structure required (debt $=0$, equity $=1$ )

$\mathrm{X}_{7}=$ Availability of collateral (value in naira)

$\mathrm{X}_{8}=$ Cost of capital in percentages

$\mathrm{X}_{9}=$ Income in naira

$\mathrm{B}_{\mathrm{i}}=$ Parameter

$\mathrm{E}_{\mathrm{i}}=$ Error term

The Enterprise cost and returns model by following Folayan and Bifarin (2013) is specified as:

$\mathrm{NEI}=\mathrm{TR}-(\mathrm{TVC}+\mathrm{TFC})$

\section{Where;}

$\mathrm{NEI}$ is the net enterprise income in naira.

TR is the total return in naira.

TVC is the total variable cost in naira.

TFC is the total fixed cost in naira.

\section{Results and Discussion}

\section{The value-added ginger products}

The identified value-added ginger products by the ginger farmers include dried ginger as indicated by $38 \%$ of the farmers as shown in Figure 1. Ginger oil was produced by $28 \%$ of the ginger farmers, ginger flakes were produced by $18 \%$ of the ginger farmers. The ginger paste was produced by $8 \%$ of the ginger farmers while the salted ginger was produced by $5 \%$ of the ginger farmers. 


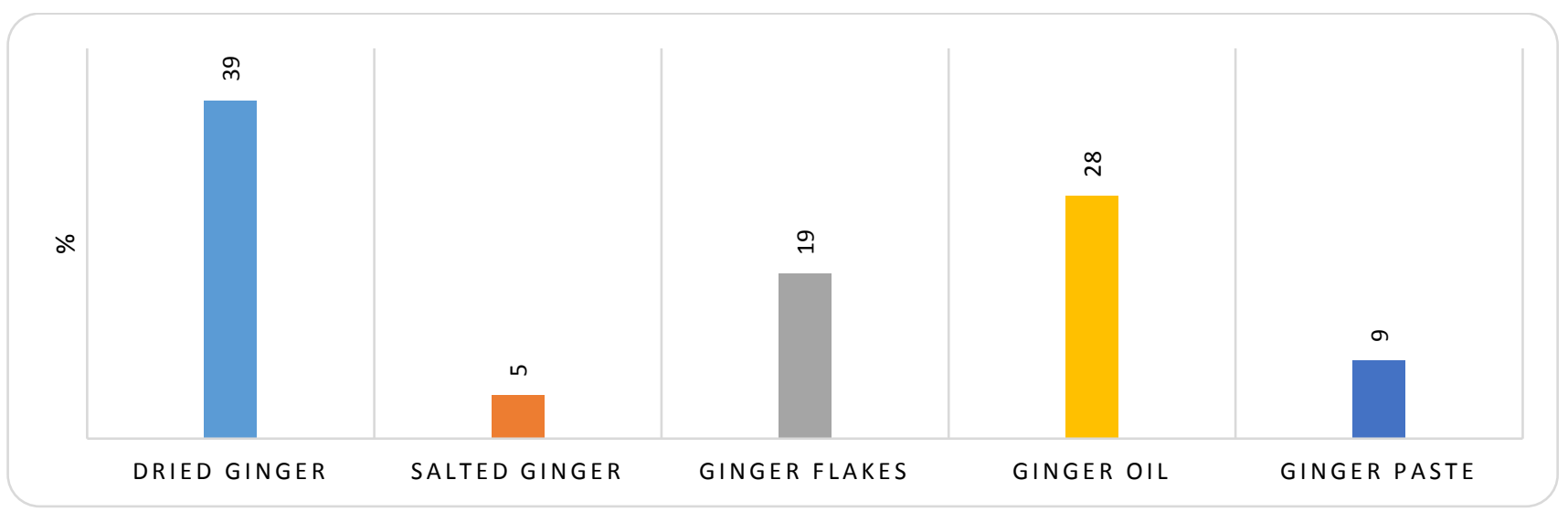

Figure 1: Value added ginger products Source: Field survey data

\section{Cost and returns analysis of ginger}

The result of the cost and returns analysis as presented in Table 1 shows that the ginger value addition by the farmers was profitable with a net margin of N5811991.4 per anum. The total variable cost accounted for 49.21 percent of the total cost of production while the total fixed cost took about 50\% of the total cost of production.

Table 1: Cost and returns of value added products

\begin{tabular}{lc}
\hline \multicolumn{1}{c}{ Item } & Amount $(\mathbf{N})$ \\
\hline Total income & $\mathbf{6 4 6 9 0 0 0 0}$ \\
\hline Input & 8086250 \\
& $(13.73)$ \\
Salaries and wages & 16172500 \\
& $(27.47)$ \\
Fuel/energy & 2021563 \\
& $(3.43)$ \\
Other variable cost & 2695417 \\
Total variable cost & $(4.58)$ \\
& $\mathbf{2 8 9 7 5 7 3 0}$ \\
Rent & $(\mathbf{4 9 . 2 1})$ \\
Levies & 5390833.3 \\
& $(9.16)$ \\
Equipment & 252695.3 \\
& $(0.43)$ \\
Other fixed cost & 8086250 \\
Total fixed cost & $(13.73)$ \\
Total cost of production & 16172500 \\
& $(27.47)$ \\
Profit & $\mathbf{2 9 9 0 2 2 7 9}$ \\
Gross margin & $(50.79)$ \\
Net earning & $\mathbf{5 8 8 7 8 0 0 9}$ \\
Return/Naira invested & $(100)$ \\
\hline
\end{tabular}




\section{Factors affecting ginger value addition}

According to the results of the linear regression model the value of $\mathrm{R}$-square was 0.98 which show that 98\% variation in the dependent variable is due to the independent variables used in the current model. The F statistics were observed to be statistically significant at $1 \%$ as shown in Table 2.

Level of education and training, the availability of collateral, and cost of capital were statistically significant at $1 \%$ and positively related to the quantity of value-added ginger. Education implies skill acquisition and training for the farmers, the more they are exposed to the required skills the more quantity of ginger produced. The availability of collateral which is very necessary for the access to capital by the farmers was available and resulted in the increase in the quantity of value-added ginger produced. Against a priori expectation, the cost of capital had a positive effect, which may imply that the cost of borrowing by the farmers was favorable to their business.

Income, source of capital, and capital structure were significant at $10 \%$ and positive except for capital structure. Income is a motivating factor for the farmers to increase their capacity to add value to the ginger. With the availability of more sources of capital, the farmers will produce more value-added ginger. The capital structure with a negative coefficient implies that most of the capital used by the ginger farmers was borrowed and this high level of debt affects their business negatively

Table 2: The impact of different factors on ginger value addition

\begin{tabular}{llclc}
\hline Variables & Coefficients & Standard Error & T-Value & Significance \\
\hline Intercept & 2331818 & 1183161 & 1.970838 & $*$ \\
Level of education and training & 44.0536 & 5.860626 & 7.51687 & $* * *$ \\
Gender & 0.081203 & 0.014456 & 5.617156 & \\
Experience & 965.2728 & 584.7935 & 1.650622 & \\
Household size & -2.68956 & 18.87451 & -0.1425 & \\
Farm size & 0.464635 & 2.399241 & 0.193659 & \\
The availability of collateral & 10.85511 & 3.082801 & 3.521185 & $* * *$ \\
The cost of capital in percentages & 1.955423 & 1.202151 & 1.626604 & $*$ \\
Income in naira & 25.60948 & 9.982401 & 2.565463 & $*$ \\
Source of capital & 637544.6 & 336457.3 & 1.894875 & $*$ \\
Capital structure & -206243 & 88000.24 & -2.34367 & $*$ \\
\hline R Square & 0.989961 & & & \\
Adjusted R Square & 0.987731 & & & \\
F statistics & $443.7711 * * *$ & & & \\
\hline
\end{tabular}

Source: Field Survey Data, 2017. $* \& * * *$ values are significant at $10 \%, \& 1 \%$ probability respectively.

\section{Conclusions}

Ginger farm enterprise was found to be very profitable as there are many value-added products that can be derived from the production. However, farmers should note that factors such as training, capital, and collateral are the major factors which are affecting the profitability of ginger value addition. Value addition training of entrepreneurs will equip them to enhance their value addition skills while the availability of capital and collateral will provide the necessary finance for acquiring the necessary value addition technology. There should be continuous skill acquisition and training of the ginger farmers. Since education was statistically significant. More extension services will be necessary for improved technology for the value addition of ginger. The provision of lowcost capital will assist farmers in value addition. For 
increased income, farmers should be encouraged to go into ginger farming.

\section{References}

Ajibade, L., Dauda, K.Y., 2005. Ginger plant; Ginger extension pamphlet. Bennard Ginger Company, Kafanchan, Nigeria

Erinle, I.D., 1988. An overview of research on ginger productions in Northern State of Nigeria. Proceedings of the first national ginger workshop, Umudike, Nigeria, 89-93.

Ewuziem, J.E., Onyenobi, V.O., 2012. Cost and return analysis of ginger production in the Guinea Savannah of Nigeria. Journal of Agriculture and Food Sciences. 10(2), 2636.

FAO., 2005. Production yearbook, Food and Agriculture Organization, Rome Italy.
FAO., 2010. Production quantity of ginger in the world total 1961-2009. Retrieved from www.fao.Mongabay.com/g/5000-World $+++/ \mathrm{T}$.

Folayan, J.A., Bifarin, J.O., 2013. Profitability analysis of honey production in Edo North Local Govt of Area of Edo State, Nigeria. Journal of Agricultural Economics and Development, 2(2), 60-64

Nto, P.O.O., Mbanasor, J.A. and Nwaru, J.C., 2011. Analysis of risk among agribusiness enterprises investment in Abia State, Nigeria. Journal of Economics and International Finance, 3(3), 187-197.

Orkwor, G.C., Melifonwu, J. O., 1988. Critical period for weeds competition in seed ginger grown from mini-setts (pp. 136-138). National Root crop Research Institute (NRCRI) 11, Umudike, Nigeria. 